\title{
Contents, Vol. 58, 1973
}

Wenger, Nanette K. (Atlanta, Ga.): The Early Ambulation of Patients After

Myocardial Infarction. Editorial Review 1

Eliakim, M.; Sapoznikov, D., and Weinman, J. (Jerusalem): Assessment of the

Atrial Contribution to Cardiac Performance by a Noninvasive Photo-

plethysmographic Technique 7

Mandecki, T. (Katowice): Incidence and Clinical Significance of Pacemaker Sounds $\quad 14$

Je1/8k, V.; Schrijen, F., and Sadoul, P. (Prague): Right Ventricular Function and Pulmonary Hemodynamics During Exercise in Patients with Chronic Obstructive Bronchopulmonary Disease 20

Oboler, A. A.; Keefe, J. F.; Gaasch, W. H.; Banas, J. S., and Levine, H. J. (Boston, Mass.): Influence of Left Ventricular Isovolumic Pressure Upon Right Ventricular Pressure Transients 30

Pathak, C. L. (Jodhpur): Autoregulation of Chronotropic Response of the Heart Through Pacemaker Stretch 45

No. 2

Armour, J. A.; L $\pi \cdot$ pincott, D. B., and Randall, W. C. (Maywood, 111.): Func tional Anatomy of the Interventricular Septum 65

Burch, G. E. and Giles, T. D. (New Orleans, La.): Atrial Vectorcardiogram in Mitral Valve Disease 80

Kostis, J. B.; Mavrogeorgis, E. A.; Horstmann, E., and Gotzoyannis, S. (Piscataway, N.J.): Effect of High Concentrations of Free Fatty Acids on the Ventricular Fibrillation Threshold of Normal Dogs and Dogs with Acute Myocardial Infarction 89

Moreyra, E.; Alday, L. E.; Madoery, R.; Buteler, B., and Amuchâstegui, L. M. (Cordoba): Use of Phentolamine as Compared to Other Tests in the Clinical Diagnosis of Muscular Subaortic Stenosis 99

Strangfeld, D.; Günther, K. H.; Bohm, Renate; Günther, Helga; Buchali, K., and Dutz, H. (Berlin): Cardiac Function in Chronic Renal Failure Before and After Hemodialysis 109 Talbot, S. (Sheffield): Fixed and Variable Coupling of Ventricular Extrasystoles 118

Book Reviews 127

Varia 128

111

Contents

No. 3

Diederich, Karl W. and Djonlagic, Hasib (Lübeck): Mechanism of Syn

chronization in Isorhythmic Dissociation 
Ioannidis, P. J.; Aravanis, C; Lekos, D., and Vasilikos C. G. (Athens): Ven tricular Repolarization during Smoking 139

Jonsson, Bengt; Olsson, Anders G., and Orö, Lars (Stockholm): Effects of Alprenolol on Central Hemodynamics and Exercise Tolerance in Patients with Angina Pectoris 150

Libanoff, Albert J. (Duarte, Calif.): A Hemodynamic Measure of Aortic Regurgitation. Half-Time of the Rate of Fall in Aortic Pressure during Diastole 162

Magnusson, G. and Hansson, E. (Södertälje): Myocardial Necrosis in the Rat: a Comparison between Isoprenaline, Orciprenaline, Salbutamol and Terbutaline 174

Matlof, Harvey J.; Bates, Brian L., and Harrison, Donald C. (Stanford, Calif.): The Hemodynamic Effects of Practolol in Experimental Myocardial Infarction 181

Book Reviews $\quad 190$

No. 4

Møller, I.; Wennevold, A., and Lyngborg, K. E. (Copenhagen): The Natural History of Pulmonary Stenosis. Long-Term Follow-Up with Serial Heart Catheterizations 193

Sannerstedt, R. (Göteborg): Comparison of Hemodynamic Responses to Exercise in Hypertensive Patients and in Healthy Subjects Given Angiotensin 203

Vohra, J. K. and Sloman, J. G. (Melbourne): Evaluation of Lidoflazine as an Anti-Anginal Drug 209

Most, A. S.; Lipsky, M. H.; Szúdlik, P. A., and Bruno, C. (Providence, R.I.): Failure of Free Fatty Acids to Influence Myocardial Oxygen Consumption in the Intact, Anesthetized Dog 220

Boddin, M.; Bogaert, A. van, and Dierick, W. (Antwerp): Catecholamines in Blood and Myocardial Tissue in Experimental Subarachnoidal Hemor rhage 229

Zochowski, R. J. and Pieniak, M. (Warsaw): Role of Regional Changes in Ventricular Performance in the Hypodynamic State Induced by Acute

Coronary Occlusion 238

Case Report

Kerin, N.; Da vies, B.; Kopelson, M., and Schwartz, H. (Cleveland, Ohio):

Paroxysmal Atrial Fibrillation in Wolff-Parkinson-White Syndrome, Type B 251

Book Reviews

256

IV

Contents

No. 5

Plass, R.; Münster, W.; Ivanov, S., and Stürmer, U. (Berlin): Angiocardiographic Diagnosis of Aortic Insufficiency in Cases of Ventricular Septal Defect Associated with Partial Prolapse of the Aortic Valve 257

MacMillan, R. M.; Rose, F. D.; Klinghoffer, J. F., and Frankl, W. S. (Philadelphia, Pa.): Case Report of Variant Angina Pectoris 273 
Johnson, P. N.; Freedberg, A. S., and Marshall, J. M. (Providence, R.I.): Action of Thyroid Hormone on the Transmembrane Potentials from Sino-atrial Node Cells and Atrial Muscle Cells in Isolated Atria of Rabbits .... 279

Gvozdják, A.; Bada, V.; Krutý, F.; Niederland, T. R., and Gvozdják, J. (Bratislava-Kramáre): Effect of Ethanol on the Metabolism of the Myocardium and its Relationship to Development of Alcoholic Myocardiopathy 296

Gavalaki, E.; Preston, T. D., and Newman, C. G. H. (London): Effect of

Frusemide on Hematocrit and Plasma Osmolality Changes Following

Angiocardiography in Children 304

Varia 312

No. 6

Klein, H. O. and Berger, H. J. (New York, N.Y. and New Haven, Conn.):

Synergistic Actions of Nitrite-/?-Adrenergic Blocking Agents in the Therapy

of Angina Pectoris. Pharmacologic and Therapeutic Rationale (Editorial

Review)

313

Bishop, V. S. and Horwitz, L. D. (San Antonio, Tex.): Influence of the Cardiac Sympathetics of Left Ventricular Dynamics during Tachycardia .... 326

Helmers, C; Hofvendahl, S.; Lundman, T.; Mogensen, L.; Nyquist, O.;

Säwe, U., and Wester, P. (Stockholm): Arterial Oxygen and Carbon-

Dioxide Tension in Patients with Acute Myocardial Infarction 335

Jonsson, B.; Szamosi, A., and Törnell, G. (Stockholm): Presystolic Mitral

Regurgitation in Severe Aortic Incompetence Observed by Cineangiography 347

Dittmer, J. E. and Goss, R. J. (Boston, Mass.): Size Changes of Auxiliary Adult

Adult Heart Grafts in Rats 355

Levi, G.; Proto, C. and Rovetta, A. (Brescia): Double-Blind Evaluation of

Practolol and Quinidine in the Treatment of Chronic Atrial Fibrillation 364

Libretti, A.; Gregorini, L., and Valentini, R. (Milan): The Effects of a New

Adrenergic Blocking Agent (K 4423) on Exercise Tolerance in Angina

Pectoris $\quad 369$

Subject Index Author Index

376379 